\title{
Analysis on the Environmental Eco-efficiency of China's Green Financial Services Based on DEA-Malmquist Model
}

\author{
Zhao Liu ${ }^{1}$ and Zuogong Wang ${ }^{2 *}$ \\ ${ }^{1}$ School of Economics, Henan University, 475001 Kaifeng, Henan, China \\ \& Henan Mechanical and Electrical Vocational College, 451191 Zhengzhou, Henan, China \\ $2^{2}$ Culture Inheritance and Innovation Center (Project Code 2020CY017), Henan University, 475001 Haifeng, Henan, China \\ \& School of Economics, Henan University, 475001 Haifeng, Henan, China \\ \& Digital Inclusive Financial Cooperation Center, Henan University, 475001 Haifeng, Henan, China
}

\begin{abstract}
Based on the development of green finance in provinces in China from 2007 to 2017, this paper makes a study on the environmental ecological efficiency of green financial services. Through the research, we can understand the development of green finance and its role in economic development
\end{abstract}

\section{Introduction}

Generally speaking, green finance serving the development of economy means that we guide capital into low-carbon, environmental protection, energy saving, emission reduction and other related industries, and serve the development of these green industries, so as to improve the whole social development and living conditions of financing, effectively curb polluting investment, alleviate or even solve the problems caused by environmental pollution to economic development. Therefore, scientifically measuring the service efficiency of China's green finance and further improving the implementation effect of green finance are the key links to realize the green development of economy and society. Based on the development of green finance in different provinces in China from 2007 to 2017, this paper makes an empirical study on the environmental ecological efficiency of green financial services and analyzes its development and change characteristics. Through the research, we can clearly understand the development of green finance and its ecological role in economic development, and lay the foundation for the next part to study the impact of green finance on the development of green economy.

\section{Literature review}

Although the current research on the efficiency of green financial services is relatively rare, the concept of environmental efficiency has been very mature, DEA model as an efficiency research method, also quite commonly used in environmental efficiency measurement1. Lin (2013) used DEA models to measure environmental efficiency in 63 countries from 1981 to 2005 and to measure energy efficiency in China from 2001 to 2010[2]. Zhang (2013) instructed the relationship among pure energy efficiency, scale efficiency and development based on SBMDEA model3. Zhang Jianqing et al .(2017) used the DEA model to measure the efficiency of sustainable development in China between 2003 and 2015, and gave relevant suggestions based on the regional differences of development efficiency4. In addition, Malmquist fullfactor analysis is a method for dynamic panel data analysis, which has been used in other fields, such as Liu Bingjie (2010), who uses the Malmquist index to evaluate the dynamic efficiency of China's steel industry5. Li Jing (2017) used DEA-Tobit to evaluate the efficiency of local government harvesting expenditure in various regions of China6. The DEA and Malmquist methods can be used to evaluate the efficiency of green financial services in China.

\section{Services Efficiency of Green Finance}

\subsection{Research design}

"DEA" is the abbreviation of Data Envelopment Analysis, a systematic analysis method developed by scholars such as Charners and Cooper based on the concept of "relative efficiency evaluation ", which is of great help to the calculation of efficiency. Charnes et al (1978) established the first DEA model -- CCR which was the most widely used model7. The Banker (1989) introduced the concept of Shepherd distance function, established a BCC model, refined the comprehensive technical efficiency CTE into pure technical efficiency and scale efficiency 8 .

By using the DEA-Malmquist model, this paper evaluated the ecological efficiency of green finance in various provincial regions of China from 2007 to 2017, which can intuitively see the role of green finance in the

\footnotetext{
* Corresponding author: Zuogong Wang 228343533@qq.com
} 
development of green economy from static efficiency and dynamic efficiency.

Firstly, the integrated efficiency, technical efficiency and scale efficiency of the decision unit (DMU) would be calculated by using mathematical linear programming and DEA model method to calculate the input $(\mathrm{X})$ and output $(\mathrm{Y})$ of the decision unit (DMU). This article selected the input-oriented BCC model with constant scale reward for DEA model analysis. Secondly, since the evaluation unit obtained by the DEA model can not compare the efficiency of different time categories, it is necessary to use the Malmquist index to construct the productivity index from the $t$ period to the $t+1$ period to measure the efficiency change and obtain the dynamic efficiency index.

\subsection{Data variable selection and sample sources}

The establishment of a unified statistical caliber is an important basis for guiding green finance and its regulatory evaluation. However, the green financial data have not yet formed authoritative statistics, and the research on the efficiency of green financial services is relatively few. Although some banking financial institutions will represent their green financial service effectiveness with the development of financial products such as green credit in social responsibility reports, so far, these financial products still do not have continuous statistics in each provincial region, and the regional flow barriers in the financial industry are real, so the general scholars tend to study green factor input to represent the effect of green financial services. However, using the data envelopment analysis method to measure green finance, we need to select the indicators of financial input and green output to study. Therefore, based on the existing research results and the principle of index selection, combined with the actual development of green finance, this paper introduces the loan balance of financial institutions, green environmental protection and environmental improvement related investment indicators as input indicators of green financial service efficiency evaluation, corresponding to environmental projects and environmental improvement as output indicators. Concretely, inputs include the $\mathrm{X}_{1}, \mathrm{X}_{2}, \mathrm{X}_{3}$, and the outputs include $Y_{1}, Y_{2}$. The statistical description of the green finance servicing evaluation indicators is shown in Table1.

The data samples involved 29 provinces in, municipalities and autonomous regions in China from 2007-2017 (due to the lack of data in Tibet and Xinjiang, the difference between the existing data and other regions is also large, in order to ensure the accuracy of the research results, the two regions are excluded). Among them, the data on the balance of loans in the financial industry are derived from the "China's Financial Statistics Yearbook" during 2008-2018, and the GDP, fiscal expenditure and urban population data are from the "Statistical Yearbook of provinces and cities" during 2008-2018, and the environmental investment and afforestation situation are from the
"China's Environmental Statistics Yearbook" during 2008-2018.

Table 1. Statistical description DEA model inputs, outputs and environmental variables indicators

\begin{tabular}{|c|c|c|c|c|c|c|}
\hline $\begin{array}{c}\text { Type } \\
\text { of } \\
\text { indicat } \\
\text { or }\end{array}$ & $\begin{array}{c}\text { Sy } \\
\text { m } \\
\text { bo } \\
\text { l }\end{array}$ & $\begin{array}{c}\text { Name } \\
\text { of } \\
\text { indicat } \\
\text { or }\end{array}$ & $\begin{array}{c}\text { Averag } \\
\text { e }\end{array}$ & $\begin{array}{c}\text { Varian } \\
\text { ce }\end{array}$ & $\begin{array}{l}\mathbf{M} \\
\mathbf{a x}\end{array}$ & $\begin{array}{c}\text { Mi } \\
\mathbf{n}\end{array}$ \\
\hline \multirow[t]{3}{*}{$\begin{array}{c}\text { Input } \\
\text { Variabl } \\
\text { es }\end{array}$} & $\mathrm{X}_{1}$ & $\begin{array}{c}\text { Regiona } \\
1 \\
\text { financia } \\
1 \text { loan } \\
\text { balance } \\
\text { (billion } \\
\text { yuan) }\end{array}$ & $\begin{array}{c}657276 . \\
8023\end{array}$ & $\begin{array}{c}1.3 \mathrm{E}+1 \\
1\end{array}$ & $\begin{array}{l}11 \\
50 \\
16 \\
4.9 \\
2\end{array}$ & $\begin{array}{c}26 \\
93 \\
45 . \\
02 \\
4\end{array}$ \\
\hline & $X_{2}$ & $\begin{array}{l}\text { Investm } \\
\text { ent in } \\
\text { regional } \\
\text { environ } \\
\text { mental } \\
\text { projects } \\
\text { (\$100 } \\
\text { million) }\end{array}$ & $\begin{array}{c}44996.1 \\
2719\end{array}$ & $1 \mathrm{E}+09$ & $\begin{array}{c}10 \\
19 \\
88 . \\
8\end{array}$ & $\begin{array}{c}88 \\
64 . \\
5\end{array}$ \\
\hline & $\mathrm{X}_{3}$ & $\begin{array}{l}\text { Regiona } \\
1 \\
\text { afforest } \\
\text { ation } \\
\text { investm } \\
\text { ent } \\
(\$ 100 \\
\text { million) }\end{array}$ & $\begin{array}{c}2876.39 \\
0045\end{array}$ & $\begin{array}{c}262354 \\
4\end{array}$ & $\begin{array}{l}51 \\
17 . \\
61 \\
74\end{array}$ & $\begin{array}{c}58 \\
4.8 \\
2\end{array}$ \\
\hline \multirow[t]{2}{*}{$\begin{array}{l}\text { Output } \\
\text { s } \\
\text { Variabl } \\
\text { es }\end{array}$} & $Y_{1}$ & $\begin{array}{l}(\%) \text { per } \\
\text { cent of } \\
\text { national } \\
\text { environ } \\
\text { mental } \\
\text { accepta } \\
\text { nce } \\
\text { projects }\end{array}$ & 96.91 & 3.4961 & $\begin{array}{l}99 . \\
89\end{array}$ & $\begin{array}{l}94 . \\
48\end{array}$ \\
\hline & $\mathrm{Y}_{2}$ & $\begin{array}{l}(\%) \\
\text { percent } \\
\text { of } \\
\text { regional } \\
\text { afforest } \\
\text { ation } \\
\text { area } \\
\text { national } \\
\text { level }\end{array}$ & 94.06 & 2.28886 & $\begin{array}{l}95 . \\
83\end{array}$ & $\begin{array}{l}91 . \\
26\end{array}$ \\
\hline
\end{tabular}

\subsection{Results and Analysis}

\subsubsection{DEA results and analysis}

From the results that calculate by Using Deap2.1 software and using BCC model, it can be seen that the proportion of provinces with comprehensive technical efficiency, pure technical efficiency and scale efficiency of green investment ecological efficiency in China between 2007 and 2017 is $24.14 \%, 34.48 \%, 27.57 \%$, $24.14 \%, 27.57 \%, 31.03 \%$, 20.69\%, 20.69\%, 24.14\%, $13.93 \%, 17.24 \%$, respectively. Meanwhile, the level of green financial efficiency and economic development level did not show a clear synchronous development trend, from the year 2007 to 2017 , only one province that 
is Inner Mongolia which has good green financial servicing efficiency that is effective in all these 11 years. And in Shanghai, Zhejiang, Henan, Guangdong, Guangxi, Yunnan, Guizhou, Gansu, Ningxia green financial the efficiency effective years are more than other provinces, but its performance characteristics are not the same in these places. Among Zhejiang, Shanghai, Henan, Gansu, green financial serving efficiency acts from high level to low efficiency. However, in Guangdong, Guizhou, Yunnan, green financial serving efficiency shows the characteristics from low efficiency to high efficiency. In Ningxia, the green financial serving efficiency is not stable and always fluctuates.

It also can be seen that the efficiency of green finance in China fluctuates greatly in the past 11 years, and the development trend is unstable. From the year 2007 to 2017, the average ecological efficiency of green finance in each provincial region of China is $0.673,0.707$ and 0.878 , respectively, which is in the low efficiency state of green finance. In addition, Table 2 shows that the three kinds of ecological efficiency of green finance showed an upward trend during the six years which is from 2007 to 2012, especially in both 2011 and 2012 when the average efficiency remained high. China's green finance efficiency has declined since 2013, followed by a few years of fluctuations. Moreover, the statistical results of the model in Table 2 show that the reasons for the ineffective comprehensive efficiency of green finance in all regions of China are caused by the inefficiency of pure technical efficiency and scale efficiency, but the low scale efficiency is the main reason for the inefficiency of comprehensive efficiency in all regions of China.

Table 2. Average efficiency of green finance 2007-2016

\begin{tabular}{|c|c|c|c|}
\hline Year & $\begin{array}{c}\text { Integrated } \\
\text { efficiency } \\
\text { crste }\end{array}$ & $\begin{array}{c}\text { vrste of } \\
\text { technical } \\
\text { efficiency }\end{array}$ & $\begin{array}{c}\text { scale of } \\
\text { scale } \\
\text { efficiency }\end{array}$ \\
\hline 2007 & 0.688 & 0.782 & 0.892 \\
\hline 2008 & 0.740 & 0.849 & 0.872 \\
\hline 2009 & 0.710 & 0.799 & 0.893 \\
\hline 2010 & 0.730 & 0.825 & 0.892 \\
\hline 2011 & 0.791 & 0.854 & 0.926 \\
\hline 2012 & 0.747 & 0.802 & 0.932 \\
\hline 2013 & 0.620 & 0.710 & 0.884 \\
\hline 2014 & 0.591 & 0.701 & 0.851 \\
\hline 2015 & 0.661 & 0.781 & 0.861 \\
\hline 2016 & 0.520 & 0.662 & 0.796 \\
\hline 2017 & 0.600 & 0.705 & 0.863 \\
\hline Average & 0.673 & 0.770 & 0.878 \\
\hline
\end{tabular}

\subsubsection{DEA-Malmquist Index Results and Analysis}

DEA measurement results of the model belong to static results, which only reflect the efficiency level of the year, and can not find the situation of technological progress. To further analyze the dynamic characteristics of green financial ecological efficiency in various provincial regions in China, this paper used the Malmquist total factor productivity index to measure the green financial data of China from 2007 to 2017 with the help of Deap2.1 software, and further analyzed the situation of the technical front surface of each decision unit (DMU). The average annual Malmquist index of the panel is as follows:

Table 3. China's Green Financial Services Malmquist Index

\begin{tabular}{|l|l|l|l|l|l|}
\hline & TERC & TC & PTEC & SEC & TEPC \\
\hline $\begin{array}{l}2007 \\
-2008\end{array}$ & 1.348 & 0.916 & 1.227 & 1.099 & 1.236 \\
\hline $\begin{array}{l}2008 \\
-2009\end{array}$ & 0.89 & 1.197 & 0.986 & 0.903 & 1.065 \\
\hline $\begin{array}{l}2009 \\
-2010\end{array}$ & 0.557 & 2.254 & 0.64 & 0.87 & 1.255 \\
\hline $\begin{array}{l}2010 \\
-2011\end{array}$ & 1.746 & 0.554 & 1.432 & 1.22 & 0.968 \\
\hline $\begin{array}{l}2011 \\
-2012\end{array}$ & 0.845 & 1.423 & 0.935 & 0.904 & 1.203 \\
\hline $\begin{array}{l}2012 \\
-2013\end{array}$ & 0.975 & 1.194 & 0.894 & 1.091 & 1.165 \\
\hline $\begin{array}{l}2013 \\
-2014\end{array}$ & 1.209 & 0.988 & 1.182 & 1.023 & 1.194 \\
\hline $\begin{array}{l}2014 \\
-2015\end{array}$ & 0.956 & 1.386 & 0.965 & 0.991 & 1.324 \\
\hline $\begin{array}{l}2015 \\
-2016\end{array}$ & 1.125 & 0.206 & 1.06 & 1.062 & 0.232 \\
\hline $\begin{array}{l}2016 \\
-2017\end{array}$ & 1.099 & 0.962 & 1.074 & 1.024 & 1.058 \\
\hline $\begin{array}{l}\text { Averag } \\
\text { e }\end{array}$ & 1.032 & 0.955 & 1.018 & 1.014 & 0.986 \\
\hline
\end{tabular}

From Table 3, we can see that the average value of technology efficiency change (TERC) during 2007 to 2017 is 1.032 , which indicates that the relative efficiency of green finance in China is still improved. the average of pure technology efficiency change (PTEC) and scale efficiency change (SEC) is 1.018 and 1.014 respectively, which indicates that the management improvement of green finance is efficient and will be close to the optimal scale in the long run. However, the average change in technology (TC) is only 0.955 , which means that green finance technology has not improved much, and this performance may eventually lead to China's green finance total factor productivity average of only 0.986 .

In addition, the annual total factor productivity fluctuation of China's green finance is obvious, with the total factor index greater than 1 in the period 2007-2010, a brief decline in 2010-2011, falling below 1, a return of more than 1 in the period 2011-2016, where the maximum is greater than 1.5 , and a return to below 1 in 2017. And the technology change index is basically consistent with the total factor productivity index, indicating that the change of total factor productivity is mainly induced by the change of technology level. However, the fluctuation of pure technology efficiency is not particularly large, which indicates that the inducement of the change of the index of whole factor change is not the only one. With the development, the innovation and management in China's green finance may affect the pure technology level of green finance together.

In the past 10 periods, the performance of total factor productivity changes in China's green financial performance was divided into 1.236, 1.065, 1.255, 0.968, 
$1.203,1.165,1.194,1.324,0.232$, 0.986. Among them, the technical level of the other seven periods was above 1 except for the period of 2010-2011, 2015-2016 and 2016-2017. It shows that China's green finance total factor productivity is more effective. However, it can be seen that the changes of total factor productivity in all provincial regions of China basically have different fluctuations in 2007-2017, among which the fluctuation of Beijing, Shanghai, Guangdong, Zhejiang and other economically more developed regions is particularly obvious indicating that the high development of the economy still has a great impact on the performance of green financial services. And according to the law of the new normal economy, China's economic growth in 20152016 steady and moderate, GDP growth slowed further, in this stage, all provincial regions have seen a sharp decline in all factor changes, the average of an unprecedented 0.232 , has reached the bottom, but also shows that the changes in economic processes have had a similar impact on the development of green finance. However, the average change in total factor productivity of green finance in 2016-2017 has rebounded and reached 1.058 of the effective range, which indicates that the slow growth state of China's economy tends to stabilize, and the green financial performance begins to be effective again.

\section{Conclusion}

Based on the DEA-Malmquist model, the ecological efficiency of green finance is analyzed statically and dynamically. It is found that the green financial ecology of China will fluctuate under both static and dynamic conditions. Among them, in the static situation, the reasons for the ineffective comprehensive efficiency of green finance in all regions of China are caused by the inefficiency of pure technical efficiency and scale efficiency, but the low scale efficiency is the main reason for the inefficiency of comprehensive efficiency in all regions of China. However, under the dynamic condition of Malmquist index intervention, the technology change index is basically consistent with the total factor productivity index, which indicates that the main inducement of the change of total factor productivity is the change of technology level, the fluctuation of technology efficiency alone is not huge, the inducement of the change of total factor change index is not unique, innovation, management and even economic development may affect the pure technology level of green finance together. It should be said that the higher the servicing efficiency of green finance indicates, the more it promotes the green economy.

\section{References}

1. R. Faere, S. Grosskopf, C.A.K. Lovell, R. E. S. J. 71, 90 (1989)

2. Y.Y. Lin, P.Y. Chen, C.C. Chen, E. M. J. 119, 134(2013)

3. N. Zhang, Y. Choi, S. S. J. 50, 225(2013)

4. J.Q. Zhang, Z Lan, G Song, R. E. J. 27, 11(2017)
5. B.L. Li, L Tan, Y.H. Lin, C. S. S. J. 1, 150(2010)

6. J. Li, S. D. M. J. 17, 166(2017)

7. A Charnes, W. W Cooper W W, Rhodes, E. J. O. R. J. 2, 429(1978)

8. R. D. Banker, A. Charners, W. W. Cooper, M. S. J. 30, 1078(1989) 